Original Research

\title{
Incidence of Colorectal Cancer in Urban Population Exposed to Cadmium
}

\author{
Danuta Rogala*, Ewa Marchwińska-Wyrwal, Anna Spychała, Ilona Hajok \\ Department of Environmental Health, School of Public Health in Bytom, \\ Medical University of Silesia in Katowice, Poland
}

Received: 10 March 2018

Accepted: 29 June 2018

\begin{abstract}
In Poland the incidence of colorectal cancer increases by $2.5 \%$ annually and differs significantly across the country. There are large inequalities in the incidence rate of colorectal cancers between 18 cities of Silesia Province. The inequalities may indicate significant impact of environmental risk factors on the development of this cancer. The aim of our study was to analyze the relationship between exposure to cadmium of the Silesian city inhabitants and the incidences of colorectal cancer in the population of men and women. In addition, the effect of exposure time on cadmium used in the study on the correlation coefficient value of the occurrence of colorectal cancer and the exposure was assessed. Studies have shown a statistically significant relationship between morbidity for colorectal cancer in the population of men and women from 18 cities of Silesia Province in 2010-2014 and the average annual concentration of cadmium in particulate matter PM10 in the years 1989-2008. A statistically significant relationship between exposure to cadmium and colorectal cancer in the population of inhabitants of Silesia Province was reported.
\end{abstract}

Keywords: colorectal cancer; incidence rate; air pollution; exposure; cadmium

\section{Introduction}

A report of the European Environment Agency (EEA) indicates that air quality in Europe, despite significant reductions in pollution levels, continues to be an important public health, environmental and economic problem [1]. Studies have shown that air pollution with particulate matter and its components, including cadmium, has a negative impact on human health, and no threshold can be established below which it would not pose a serious threat [2-4]. It is estimated that air pollution by particulate matter accounts for nearly

*e-mail: drogala@sum.edu.pl
0.5 million premature deaths in Europe each year [1]. In 2013, the International Agency for Research on Cancer (IARC) classified particulate matter and air pollutants into group 1 of carcinogenic substances for humans [5].

Colon cancer is currently the third most common cancer (1.2 million new cases per year) and the fourth most common cause of death in the world $(600.000$ deaths per year) $[6,7]$. The incidence of this type of cancer increases with age. Most cases occur at the age of 70 and after [8]. According to the World Health Organization (WHO), in 2012 most cases of colorectal cancer were diagnosed in the European Union (68.0/10 inhabitants) and in the most developed regions in the world (59.2/10 inhabitants); the least in the African 
region $\left(3.5 / 10^{5}\right.$ inhabitants) and India (5.1/10 inhabitants) [9].

In high-income countries, including the United States, the incidence of colorectal cancer decreased, which may be due to increased access to screening (colonoscopy) [10]. In Poland, the incidence of colorectal cancer increases by $2.5 \%$ annually; every year 30 to 35 new cases per 100.000 inhabitants are recorded [11].

The development of colorectal cancer is influenced by environmental risk factors, genetic predisposition and co-occurrence of certain diseases. Approximately $80 \%$ of colorectal cancer cases are caused by genetic and environmental risk factors [12]. Important factors that increase the likelihood of developing colorectal cancer are exposure to harmful substances in the environment and in the inhaled air. These compounds include: benzo[a]pyrene, asbestos, nitrosamines, vinyl chloride, polypropylene, acrylonitrile, synthetic fibers, ethyl alcohol, tobacco smoke and heavy metals such as cadmium and lead [13].

According to WHO data, in the 1990s the cadmium concentration in atmospheric air in Europe was measured in the range of $0.2-1 \mathrm{ng} \mathrm{m}^{-3}$ [14]. In 2003, the average concentration of cadmium in the air was lower in the central part of Europe (from 0.2 to $0.5 \mathrm{ng} \mathrm{m}^{-3}$ ) and much lower in Northern Europe ( 0.05 to $0.2 \mathrm{ng} \mathrm{m}^{-3}$ ) [14]. In Silesia Province, cadmium concentration in air has always been very high due to numerous mining and processing plants of non-ferrous metals in the area. The average concentration of cadmium in the air in 1989-2002 was $5.6 \mathrm{ng} \mathrm{m}^{-3}$ in the central part of Silesia Province [15-18].

In this part of the country, air quality has been bad, but progressively improved over the years, resulting in an average annual concentration of cadmium in particulate matter PM10 in 2003-2016 already at $2.5 \mathrm{ng} \mathrm{m}^{-3}$ and in the last 5 years $(2012-2016)$ is $0.99 \mathrm{ng} \mathrm{m}^{-3}[19]$.

The aim of our study was to analyze the relationship between exposure to cadmium of the Silesian city inhabitants and the incidences of colorectal cancer in the population of men and women. In addition, the effect of exposure time to cadmium used in the study on the correlation coefficient value of the occurrence of colorectal cancer and exposure was assessed.

\section{Material and Methods}

The study investigated the association between the incidence of colorectal cancer in the urban population and the concentration of cadmium in particulate matter (PM10) that women and men were exposed to. The research material were epidemiological data obtained from the National Cancer Registry (NCR) on the incidence of colorectal cancer (C18-21) in the population of men and women in 18 cities in Silesia Province in 2010-2014: Bielsko-Biala, Bytom, Chorzow, Czestochowa, Dabrowa Gornicza, Gliwice, Jastrzebie-
Zdroj, Jaworzno, Katowice, Myslowice, Piekary Slaskie, Ruda Slaska, Rybnik, Siemianowice Slaskie, Sosnowiec, Tychy, Zabrze and Zory. From the local data bank of the Central Statistical Office (GUS), data on the number of male and female population for 2010-2014 were collected in these cities. The average population of women and men across 18 cities in this period of time was 1.332.237 (female) and 1.227.516 (male).

These data allowed us to calculate the average incidence rates for colorectal cancer (C18-21) for 18 cities in Silesia Province in the analyzed period of time (2010-2014), estimated at 100.000 women and men. The concentrations of cadmium in air are measured by automatic monitoring stations located in Silesian cities. The average annual concentrations data of cadmium in air were taken from the reports of the Voivodship Inspectorate of Environmental Protection in Katowice in order to estimate the exposure rate to cadmium of the inhabitants of Silesian cities.

To assess the effect of exposure time to cadmium on the correlation coefficient value of the occurrence of colorectal cancer, two different exposure times were used in the study: from 1999 to 2008 and 1989-2008.

For statistical analysis of the collected material, the R-Spearman rank test was adopted using the Statistica 12 program from StatSoft Polska.

\section{Results}

In all analyzed cities of Silesia in 2014, 1211 cases of colorectal cancer were diagnosed: 697 cases $(58 \%)$ in men and 514 cases (42\%) in women. Analysis of the data presented in Table 1 shows a variety in the incidence of colorectal cancer in men and women. The incidence rates of colorectal cancer in the analyzed period 2010-2014 are characterized by an upward trend in most cities of Silesia Province, and only 4 of them show a decrease in morbidity in colorectal cancer in that period. The morbidity increase in extreme cases (the population of women in Siemianowice Slaskie) reached 200\% (Table 1).

Table 1 presents the crude morbidity for colorectal cancer in men and women at the beginning and end of the study period. The average value of the morbidity rate in this period (2010-2014) is shown in Fig. 1.

The indicated rates of colorectal cancer in the population of men and women in 18 selected cities (Fig. 1) differs significantly. The highest incidence of colorectal cancer was found in the populations of women in Czestochowa, Piekary Slaskie and Sosnowiec, and the lowest in Myslowice, Zory and Jaworzno. The average morbidity rates of colorectal cancer in the male population is $50.9 / 10^{5}$. The highest incidence rates were found in Piekary Slaskie, Gliwice and Bielsko-Biala, and the lowest in Myslowice, Zory and Sosnowiec (Fig. 1).

It has been assumed that cadmium may be an important risk factor for incidences of colorectal cancer 
Table 1. Incidence of colorectal cancer in selected cities of Silesia Province in 2010 and 2014.

\begin{tabular}{|c|c|c|c|c|c|}
\hline \multirow{3}{*}{ No. } & \multirow{3}{*}{ City } & \multicolumn{2}{|c|}{ Women } & \multicolumn{2}{|c|}{ Men } \\
\hline & & \multicolumn{4}{|c|}{ The crude incidence rate per 100.000 women / men } \\
\hline & & 2010 & 2014 & 2010 & 2014 \\
\hline 1 & Bielsko-Biala & 50.9 & 53.9 & 61.9 & 63.5 \\
\hline 2 & Bytom & 48.9 & 49.7 & 41.1 & 46.8 \\
\hline 3 & Chorzow & 32.5 & 41.9 & 71.3 & 44.9 \\
\hline 4 & Czestochowa & 39.8 & 58.3 & 47.5 & 48.4 \\
\hline 5 & Dabrowa Gornicza & 27.6 & 28.7 & 46.1 & 63.9 \\
\hline 6 & Gliwice & 35.0 & 40.6 & 68.4 & 51.2 \\
\hline 7 & Jastrzebie-Zdroj & 34.0 & 38.2 & 35.1 & 45.4 \\
\hline 8 & Jaworzno & 28.7 & 22.1 & 34.7 & 50.0 \\
\hline 9 & Katowice & 35.5 & 43.2 & 47.9 & 61.9 \\
\hline 10 & Myslowice & 36.1 & 22.0 & 32.7 & 28.4 \\
\hline 11 & Piekary Slaskie & 39.8 & 55.2 & 68.1 & 108.2 \\
\hline 12 & Ruda Slaska & 27.1 & 39.6 & 41.6 & 46.9 \\
\hline 13 & Rybnik & 26.3 & 38.0 & 36.3 & 51.6 \\
\hline 14 & Siemianowice Slaskie & 27.3 & 57.9 & 38.6 & 44.7 \\
\hline 15 & Sosnowiec & 30.8 & 44.3 & 53.3 & 43.6 \\
\hline 16 & Tychy & 31.4 & 25.8 & 47.8 & 48.0 \\
\hline 17 & Zabrze & 38.5 & 45.6 & 46.7 & 56.7 \\
\hline 18 & Zory & 41.2 & 26.3 & 29.4 & 53.7 \\
\hline
\end{tabular}

Source: Based on data from the National Cancer Registry and the Central Statistical Office

a)

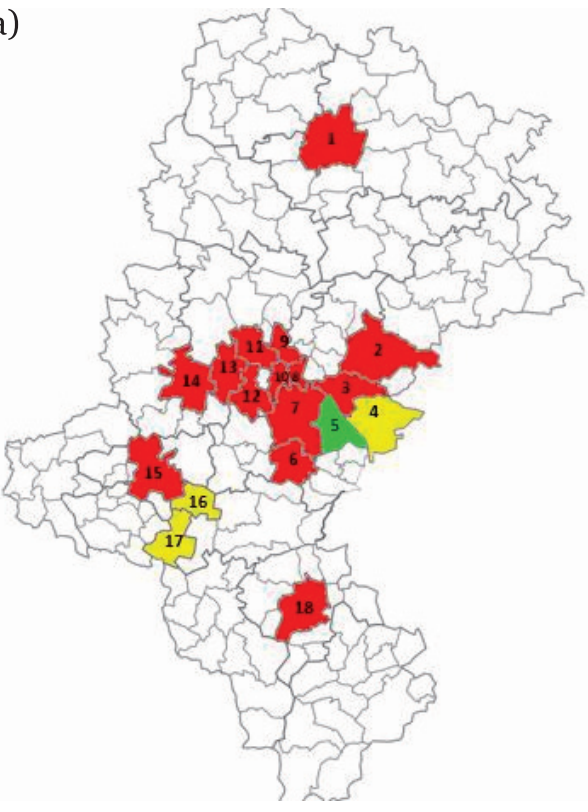

b)

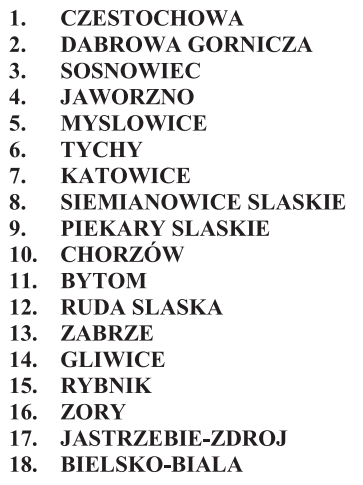

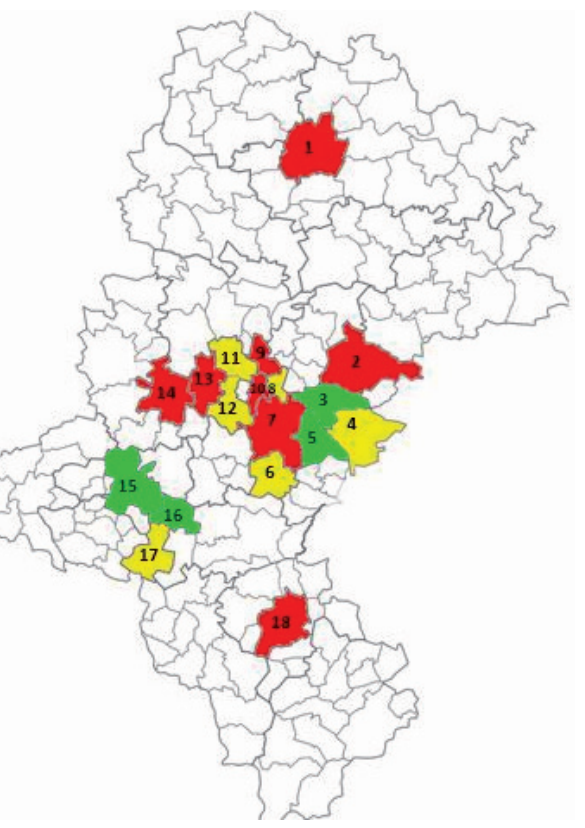

$>39.9$ The average value for cities of the Silesia Province for the years 2010-2014 $\geq 28.2$ The average value for cities not marked in red color $<28.2$
$>50.9$ The average value for cities of the Silesia Province for the years 2010-2014 $\geq 45.8$ The average value for cities not marked in red color $<45.8$

Fig. 1. Crude indicated rates of colorectal cancer in populations of a) women and b) men (per 100.000 women / men); average value of the morbidity rate in 2010-2014 in 18 cities of Silesia Province.

Source: Based on data from the National Cancer Registry and the Central Statistical Office 


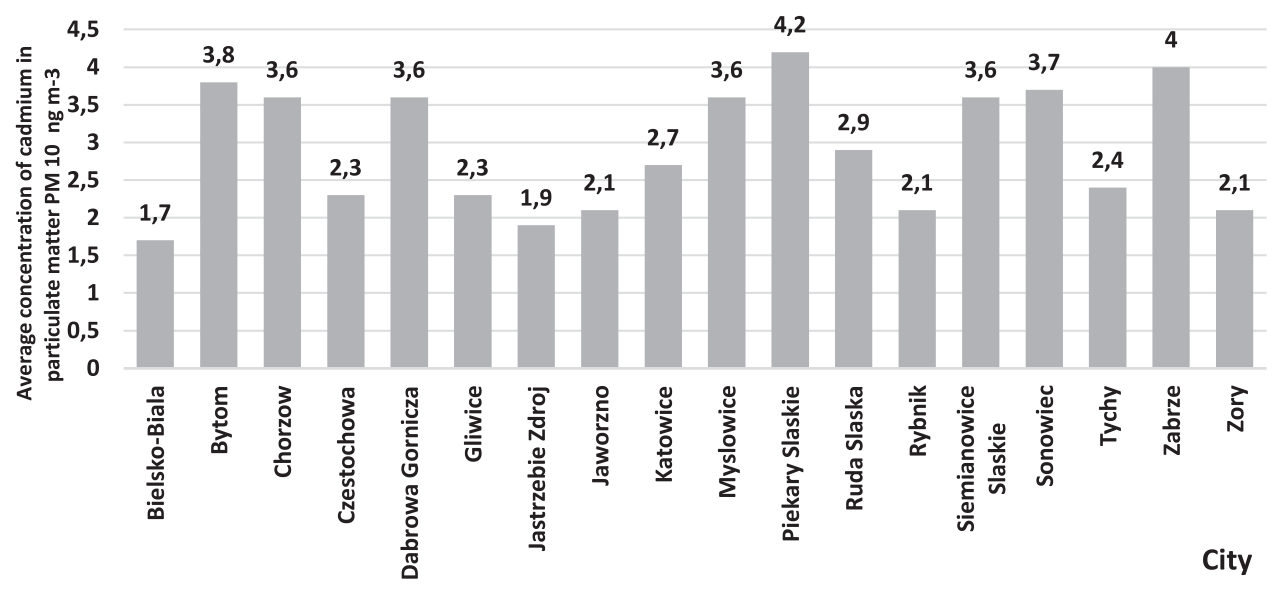

Fig. 2. Average concentration of cadmium in the air in 1999-2008 in selected cities of Silesia Province.

because it occurs in the air of all analyzed cities at different concentrations. To confirm the validity of this assumption, the relationship between exposure to cadmium of men and women in selected cities and the morbidity on this type of cancer was examined using statistical methods.

The differences between the highest and the lowest average concentrations of cadmium in the cities selected for research in the considered period of time is about $60 \%$. The highest values were recorded in Piekary Slaskie, Zabrze and Bytom, and the lowest in BielskoBiala and Jastrzebie Zdroj (Fig. 2).

Studies have shown a statistically significant relationship between morbidity for colorectal cancer in the population of men and women from 18 cities of Silesia Province in 2010-2014, and the average annual concentration of cadmium in particulate matter PM10 in 1999 and 2008. The correlation coefficient for the female and male population indicates average correlations of $\mathrm{R}=0.48$ and $\mathrm{R}=0.54$ respectively (Table 2).
The correlation coefficient increases as the longer time exposure to cadmium of the study population was used, particularly in the case of women (Table 3).

\section{Discussion}

The results of this study show a high differentiation of morbidity for colorectal cancer in the cities of central Silesia, which could indicate a significant contribution of environmental risk factors that develop this cancer. According to numerous scientific reports, particulate matter is an important risk factor for human health. The particles of dust on their surface absorb toxic and carcinogenic compounds, including heavy metals [20]. The inhabitants of each city of Silesia are exposed to the particulate matter PM10, which contains many pollutants typical for the region, including such a carcinogen as cadmium [20].

The studies have shown a significant relationship between air pollution by cadmium and incidence rate

Table 2. Relationship between average concentrations of cadmium in PM10 in the shorter exposure time (1999-2008) and morbidity for colorectal cancer in selected cities of Silesia Province.

\begin{tabular}{|c|c|c|c|}
\hline \multicolumn{2}{|c|}{ Variable } & $\mathrm{p}$-value & $\mathrm{R}$ - correlation coefficient \\
\hline The incidence rate of colorectal cancer in women & $\begin{array}{c}\text { The average concentration } \\
\text { of cadmium in PM10 for the } \\
\text { years 1999-2008 }\left[\mathrm{ng} \mathrm{m}^{-3}\right]^{*}\end{array}$ & $\mathrm{p}<0.048$ & $\mathrm{R}=0.48$ \\
\cline { 1 - 4 } The incidence rate of colorectal cancer in men & $\mathrm{p}<0.037$ & $\mathrm{R}=0.54$ \\
\hline
\end{tabular}

*Our study did not include the cities of Bielsko-Biala and Czestochowa due to lack of measurements of cadmium in 1989-1998.

Table 3. Relationship between average concentrations of cadmium in PM10 at a longer exposure time (1989-2008) and morbidity for colorectal cancer in selected cities of Silesia Province.

\begin{tabular}{|c|c|c|c|}
\hline \multicolumn{2}{|c|}{ Variable } & $\mathrm{p}$-value & R-correlation coefficient \\
\hline The incidence rate of colorectal cancer in women & $\begin{array}{c}\text { The average concentration } \\
\text { of cadmium in PM10 for the } \\
\text { years 1989-2008 }\left[\mathrm{ng} \mathrm{m}^{-3}\right]^{*}\end{array}$ & $\mathrm{p}<0.03$ & $\mathrm{R}=0.54$ \\
\cline { 1 - 3 } The incidence rate of colorectal cancer in men & $\mathrm{p}<0.03$ & $\mathrm{R}=0.53$ \\
\hline
\end{tabular}

*Our study did not include the cities of Bielsko-Biala and Czestochowa due to lack of measurements of cadmium in 1989-1998. 
of colorectal cancer in women and men. The health effects of poor air quality are most commonly observed in urban areas [21].

The conducted research showed that air pollution by cadmium differs significantly between cities of Silesia. In Poland, the main source of dust emissions into the air is the burning of solid fuels apart from the industry, mainly in the residential sector. According to the National Centre for Emissions Management (KOBiZE), the residential sector accounts for around $49 \%$ of dust emissions to the atmosphere [22]. Large spatial disparities in the health effects of air pollution with particulate matter occur in many countries in the world [23]. One of the strengths of this study was that Silesia Province provides a unique opportunity to examine the relationship between specific pollutants such as cadmium and colon cancer because of the concentration of cadmium emission sources and history of environmental monitoring.

Our study did have some limitations that should be noted. One of them is studying only cadmium as a risk factor for colorectal cancer, which is an important but not the only carcinogenic component of air pollution.

According to the literature, the incidence of colorectal cancer is characterized by dynamic growth in Poland. It this research an analysis of male and female populations were conducted separately, considering that the risk of colorectal cancer is higher in men than in women. Colorectal cancer accounts for $12 \%$ of all cancer cases in the male population and $10 \%$ in the female population [7, 19]. In recent decades, the 5-year relative survival rate for colorectal cancer has improved in high-income countries such as Australia, Canada and the United States and ranges $65 \%$, while in low-income countries this indicator does not exceed $50 \%$ [24]. This indicator depends on the stage of cancer and age of the patient [18]. In Poland, colorectal cancer accounts for $12 \%$ of all cancer deaths. The 5-year survival rate does not exceed $25 \%$ and is one of the worst in Europe $[18,25]$. The constantly increasing incidence rate and cancer deaths are mainly due to poor public awareness of primary prevention; preventing morbidity by reducing exposure to the modifiable risk factors current in the human environment. Results from studies carried out and presented here indicates one of the ways of identification of environmental risk factors. A significant problem is also the low level of motivation to pursue a healthy lifestyle in order to reduce the risk of cancer [11].

\section{Conclusions}

1. Large inequalities in the incidence rate of colorectal cancers in selected cities of Silesia Province may indicate the impact of environmental risk factors on the development of this cancer.
2. The average annual concentrations of cadmium in particulate matter PM10 is characterized by differentiation on the area of 18 analyzed cities.

3. Studies have shown a significant relationship between air pollution by cadmium and incidence rate of colorectal cancer of women and men and the correlation coefficient increasing according to the duration of exposure to cadmium.

\section{Acknowledgements}

This research was supported by Medical University of Silesia in Katowice by the grant No. KNW-1-094/N/7/Z.

\section{Conflict of Interest}

The authors declare no conflict of interest.

\section{References}

1. European Environment Agency. Air quality in Europe - 2013 report. Report No 9/2013. Available online: http://www.eea.europa.eu//publications/air-quality-ineurope-2013. (accessed on 29.10.2017).

2. DOBARADARAN S., GERAVANDI S., GOUDARZI G., IDANI E., SALMANZADEH S., SOLTANI F., YARI A.R., MOHAMMADI M.J. Determination of Cardiovascular and Respiratory Diseases Caused by PM10 Exposure in Bushehr. 2013. J Mazandaran Univ Med Sci., 26 (139), 42, 2016.

3. European Environment Agency. Air quality in Europe 2014 report. Report No 5/2014. Available online: https:// www.eea.europa.eu/publications/air-quality-in-europe2015\#tab-data-references (accessed on 29.10.2017).

4. KHAEFI M., GOUDARZI G., YARI A.R., GERAVANDI S., DOBARADARAN S., IDANI E., JAVANMARDI P., YOUESFI F., HASHEMZADEH B., SHAHRIARI A., JAVAD M.M. An association between ambient pollutants and hospital admitted respiratory cases in Ahvaz. Iran. Fresen Environ Bull., 25 (10), 3955, 2016.

5. LOOMIS D., GROSSE Y., LAUBY-SECRETAN B., EL GHISSASSI F., BOUVARD V., BENBRAHIM-TALLAA L., GUHA N., BAAN R., MATTOCK H., STRAIF K. The carcinogenicity of outdoor air pollution. Lancet Oncology, 14, 1262, 2013.

6. FERLAY J., SHIN H.R., BRAY F., FORMAN D., MATHERS C., PARKIN D.M. GLOBOCAN 2008 cancer incidence and mortality worldwide: IARC Cancer Base No 10. Lyon: International Agency for Research on Cancer, 2010.

7. STEWARD B.W., WILD C.P. World Cancer Report 2014. International Agency for Research on Cancer. World Health Organization. Lyon, 2014.

8. SIEGEL R., DESANTIS C., VIRGO K., STEIN K., MARIOTTO A., SMITH T., COOPER D., GANSLER T., LERRO C., FEDEWA S., LIN C., LEACH C., CANNADY R.S., CHO H., SCOPPA S., HACHEY M., KIRCH R., JEMAL A., WARD E. Cancer treatment and survivorship statistics. 2012. CA Cancer J. Clin., 62, 220, 2012. 
9. GLOBCAN 2012. Estimated Cancer Incidence. Mortality and Prevalence Worldwide in 2012. World Cancer Report. International Agency for Research on Cancer, 2014.

10. CENTER M.M., JEMAL A., WARD E. International trends in colorectal cancer incidence rates. Cancer Epidemiol. Biomarkers Prev., 18, 1688, 2009.

11. ZYŚK R., WYSOCKI P., WYRWICZ L. Colorectal cancer - the social significance of changes in the epidemiology and treatment options in Poland. Onkol. Prakt. Klin., 10 (4), 212, 2014 [In Polish]

12. GIL J., STEMBALSKA A., ŁACZMAŃSKA I., SĄSIADEK M. Sporadic colorectal cancer - factors modulating individual susceptibility to cancer. Współcz. Onkol., 14 (3), 211, 2010 [In Polish].

13. KLIMCZAK A., KUBIAK K., CYBULSKA M., KULA A., DZIKI Ł., MALINOWSKA K. Etiology of colorectal cancer and antioxidant barrier of the organism Pol. Merk. Lek., 28 (165), 223, 2010 [In Polish]

14. World Health Organization. Health risks of heavy metals from long-range transboundary air pollution. Copenhagen, 2007.

15. The Voivodship Sanitary and Epidemiological Station in Katowice. Average air pollutants in the Silesia province in the years 1989-1990. Katowice, 1990-1991 [In Polish].

16. The Voivodship Sanitary and Epidemiological Station in Katowice. Air pollutants in the Katowice province in the years 1991-1999. Katowice, 1990-2001 [In Polish].

17. The Voivodship Sanitary and Epidemiological Station in Katowice. Air pollutants in the Silesia province in the years 2000-2002. Katowice, 2002-2003 [In Polish].
18. WOJCIECHOWSKA U., DIDKOWSKA J., ZATOŃSKI W. Cancer in Poland in 2010. Center of Oncology - Maria Sklodowska-Curie Warsaw, 2012 [In Polish].

19. KUBIAK A., KYCLER W., TROJANOWSKI M. Epidemiology and prevention of colorectal cancer in Poland. Probl. Hig. Epidemiol., 95 (3), 636, 2014 [In Polish].

20. KUSKOWSKA K., DMOCHOWSKI D. Analysis of Concentrations of Particulate Matter $\mathrm{PM}_{10}, \mathrm{PM}_{2.5}$ and PM1.0 at Different Heights of the Gdański Bridge. Zeszyty Naukowe SGSP, 59 (3), 101, 2016 [In Polish].

21. International Agency for Research on Cancer. Outdoor air pollution a leading environmental cause of cancer deaths. France; Press Release No 221, 2013.

22. Chief Inspectorate for Environmental Protection. State of the environment in Poland. Signals 2016. Library of Environmental Monitoring. Warsaw, 2017 [In Polish].

23. Inspection for Environmental Protection. Fine dust in the atmosphere. Compendium of knowledge about air pollution with particulate matter in Poland. Library of Environmental Monitoring. Warsaw, 2016 [In Polish].

24. BRENNER H., KLOOR M., PAX CH.P. Colorectal cancer. Lancet, 383, 1490, 2014.

25. The National Program for Combating 2006-2015. Warsaw 2008. Available online: http://www2.mz.gov.pl/wwwfiles/ ma_struktura/docs/opis_zadan_3092009p.pdf (accessed on 28.10.2017). [In Polish] 